\title{
Attitudinal and Behavioural Loyalty: Zimbabwe Tourism Brand Performance Ascendancy
}

\author{
Farai Chigora (Corresponding author) \\ Faculty of Commerce, Catholic University of Zimbabwe, Zimbabwe \\ E-mail: fchigora@yahoo.com Tel: 263-772-886-871 \\ Promise Zvavahera \\ National University of Science and Technology, Zimbabwe \\ E-mail: promisezvavahera59@gmail.com Tel: 263-773-471-703
}

\author{
Received: July 31, 2015 Accepted: August 25, 2015 Published: November 9, 2015 \\ doi:10.5296/bmh.v3i2.8546ＵRL: http://dx.doi.org/10.5296/bmh.v3i2.8546
}

\begin{abstract}
The study investigated the most common sources of brand loyalty in Zimbabwe's tourism destination. This was based on two dominant sources of brand loyalty which are attitudinal and behavioural loyalty. The main reason for the study was that Zimbabwe's tourism brand is underperforming due to various socio-economic and political factors such that authorities should know on the most prevailing source of brand loyalty. This helps in formulating strategies that turn either attitudinal or behavioural loyalty to better Zimbabwe tourism brand performance. The study used a sequential mixed methods research design which is a combination of both qualitative and quantitative approaches. In-depth interviews were carried out with various experts from the tourism industry in order to come up with the common sources of tourist loyalty in Zimbabwe. The identified variables were personal experience, general perception, media propaganda, word of mouth reference and speculations. These variables were then investigated as sources of brand loyalty through survey questionnaires that were distributed in the Zimbabwe tourism accommodation sector and resorts. The results showed that the most effective source of brand loyalty is media propaganda followed by word of mouth reference then speculation, personal experience and general perception. The most common sources have been classified as attitudinal effects and that study recommended effective media publicity management, sponsored familarisation tours and tourism brand showcasing partnerships at both regional and international levels.
\end{abstract}

Keywords: attitudinal, behavioural, loyalty, Zimbabwe, tourism, brand performance 


\section{Introduction}

Zimbabwe tourism destination brand is in a dire situation with many traditional and potential tourists directing their visit to other competing destinations. The country has faced various negative trends over the years. These have been triggered mainly by changes in the country's socio-economic and political environment (Chibaya, 2013; Chikafu, Mirimi, \& Hurombo, 2014). Traditionally the Zimbabwe tourism destination has relied on Western tourist particularly from Britain and German. However, following such events as the land reform program in the year 2000 the colonial ties between Zimbabwe and the Western community has been cut. This has crippled the tourism industry in Zimbabwe as the Western markets used to be the most dominant and vibrant source of tourism business. Various survival strategies have been implemented by tourism destination marketers spearheaded by the Zimbabwe Tourism Authority. These included the Look East policy whereby tourism marketing efforts have routed to the Asia communities of the world. The ultimate effect is a change in the type of tourists who have different tastes and preferences. The major challenge that has been observed is the difference in spending patterns of the new tourists as compared to the traditional Western capitalists. The new Asian tourists have been regarded as "High Volume, Low Value" as compared to the traditional "Low Volume, High Value.” This as a single strategy to move from the Western to East markets can be reckoned as a business of volumes rather than value which does not improve the destinations margins. Therefore, in order to survive from this downfall perceptional strategies should be established and managed so as to attract more tourists like in the years just after the country's independence. This calls for destination marketers to understand the major drivers of Zimbabwe tourism destination's brand loyalty. According to Reynolds and Arnold (2000) the concept of customer loyalty is becoming vital to the operation of businesses. Brand loyalty can be viewed from two perspectives namely behavioural and attitudinal loyalty (Kumar \& Shah, 2006; Lam et al. 2004; Fullerton, 2005). When destination marketers know and appreciate the source of loyalty for their tourists, they can craft policies and campaigns that turn their mindset to consume the country's tourism offerings. The study therefore assessed the sources of tourist loyalty in Zimbabwe tourism destination with an aim to discover if they are inclined to either behavioural or attitudinal loyalty. This is because the two loyalty variables are regarded as equally important (Bove et al., 2009). The aim of the study was to understand the influencers of tourism loyalty for Zimbabwe in order to capitalise for a better tourism brand performance.

\section{Problem statement}

The Zimbabwe tourism destination brand is in a dire state suffering from intense negative publicity from international media. Zimbabwe destination marketers are engaging in various promotional campaigns in order to rejuvenate the brand. However, there is a lack of conceptualization on the most viable source of brand tourists' brand loyalty. The study investigated the most two dominant sources of brand loyalty which are attitudinal and behavioural and their effect on the Zimbabwe tourism brand performance. 


\section{Literature Review}

Customer loyalty is represented by the ability to have a sense of belonging in the affairs (employees, services and products) of an organisation thus causing a direct impact on customer behaviour (Jones \& Sasser, 1995). This can be seen when tourists feel as part of a tourism destination, they will always visit the same tourist destination for a holiday. Also Shih-I (2011) alluded that the sense of identification that comes from customer loyalty affect purchase decisions, ability to recommend others to purchase, spending of money and the eagerness to be part of the business. Bloemer and Odekerken-Schroder (2002) concurred by stipulating that customer loyalty is constructed from a multi-dimension which includes price tolerance, purchase intensions, word of mouth, propensity to leave and complaint behaviour. Therefore, Chaudhuri and Holbrook (2001) have used both behavioural and attitudinal loyalty as the drivers that contribute to market share and reviewed that there is an interrelated behaviour between the two variables. This means that it is critically essential to analyse how each one of these variables contribute to a tourism destination market share. There is a commonality in various researches that attitudinal loyalty is a predecessor of behavioral loyalty (Bandyopadhyay \& Martell, 2007; Carpenter, 2008). In contrast Day (1969) alluded that behavioural loyalty happens because of a chance and does not have necessarily lead to attitudinal loyalty. Sharp et al. (2002) went on to propound that they is a low relative between attitudinal and behavioral loyalty. Therefore in order to separate the two concepts Shih-I (2011) announced behavioural loyalty as a substantial element and attitudinal as a psychological construct. Therefore the gaps in the existing literature calls for an in-depth investigation on the variables that makes both behavioural and attitudinal loyalty in Zimbabwe's tourism destination with an aim to uplift the country's tourism brand performance.

\section{Methodology}

The research used a qualitative to quantitative sequential mixed method. The qualitative research design helped in establishing the most accepted sources of both attitudinal and behavioural loyalty in Zimbabwe tourism destination from various experts in the tourism industry. These sources were analysed in terms of their relationship with brand loyalty through survey questionnaires. The total population was 80 respondents with 65 selected from the accommodation sector and 15 from tourism resorts.

\section{Findings and Discussions}

The research used an in-depth interview to establish the most common variables that promotes brand loyalty in the Zimbabwe tourism destination. The responses from various experts and senior managers in the tourism destination agreed that the most known sources of brand loyalty in Zimbabwe tourism destination are personal experience, general perceptions, media propaganda, word of mouth reference and speculations. These were investigated on their relationship to behavioural and attitudinal loyalty using survey questionnaires that were distributed to tourism operators in the accommodation and resorts sectors and the results are as shown in table 1 below. 
Table 1. Brand loyalty Sources Relation to Attitudinal and Behavioural loyalty

\begin{tabular}{|l|l|l|}
\hline Sources of Brand Loyalty & Behavioral Loyalty & Attitudinal Loyalty \\
\hline $1 . \quad$ Personal experience & 1.101 & 2.791 \\
\hline 2. $\quad$ General perception & 1.660 & 3.226 \\
\hline 3. $\quad$ Media propaganda & 2.167 & 1.002 \\
\hline 4. $\quad$ Word of mouth reference & 2.301 & 1.113 \\
\hline 5. $\quad$ Speculation & 1.553 & 2.017 \\
\hline
\end{tabular}

Note. The average mean are in a range of 1-5 (1= Strongly Agree; 5=Strongly Disagree).

Source: Research Survey (2015).

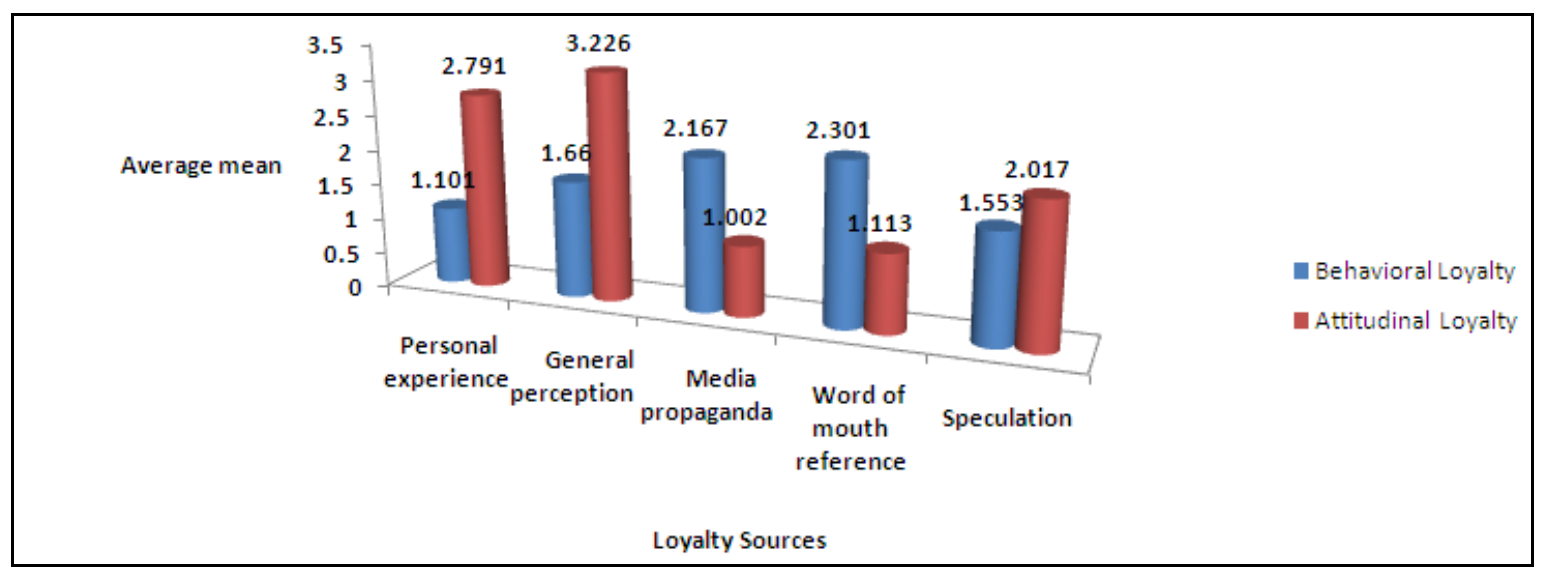

Figure 1. Brand loyalty sources relation to attitudinal and behavioural loyalty

Note. The average mean are in a range of 1-5 (1= Strongly Agree; $5=$ Strongly Disagree).

Source: Research Survey (2015).

Personal Experience: The statistics in table 1 and figure 1 above shows that personal experience is inclined to behavioural loyalty (behavioural loyalty $=1.101$ against attitudinal =2.791). Personal experience average mean (1.101) is inclined to 1 which is representing a "strongly agree" that it is behavioural loyalty. An average mean of 2.791 is relatively far from 1 meaning that it is towards 5 related to "strongly disagree." Therefore, it shows that the majority of the respondents agreed that behavioural loyalty is mainly triggered by personal experience that the tourists had with the destination. This is the experience that is gained after a direct visit to a destination. It is the behaviour to repeat purchase that is triggered by personal experience. When individuals or groups visit Zimbabwe as a tourism destination the experiences they get will encourage or discourage the desire to be loyal and visit again in the future. This means that tourism destination managers in Zimbabwe must ensure that tourist get a maximum satisfaction in their experience as it encourages them to come back again and improve the destination's brand identity and position.

General Perception: Table 1 and figure 1 reveals that general perception of the tourists affects behavioural loyalty more than attitudinal 1.66 and 3.226 respectively. The statistical average mean of 1.66 is next to 1 in the range of 1 to 5 . The average mean of 1 is a "strongly 
agree" meaning that the respondents highly agreed that general perception affects behavioural loyalty more than attitudinal loyalty. This is because attitudinal brand loyalty has an average mean of 3.226 which is close to 5 instead of 1 meaning that the respondents "strongly disagree” that it general perception leads to attitudinal brand loyalty. Perception is a direct behaviour that is driven by the mind of an individual towards a certain brand or destination. This is because what comes in the mind of an individual shapes the way he or she views and perceive a certain brand thus triggering a certain behaviour that encourages or deter visit to a tourism destination. Though perception is difficult to manage as it is subjective and differs from one individual to another, Zimbabwe destination marketers should strive to improve its brand image as it helps in creating a positive perception in the mind of the tourists.

Media propaganda: As shown in table 1 and figure 1 the research revealed that the majority of respondents announced that media propaganda is related to attitudinal loyalty (1.002) more than behavioural loyalty (2.167). The average means shows that respondents where "strongly agreeing" that media propaganda affects attitudinal brand loyalty. This is because an average mean of 1.002 is highly related to 1 than 5 making it a "strongly agree" that it brings to attitudinal brand loyalty more than behavioural loyalty. The respondents showed a 2.167 average mean for behavioural loyalty which is relatively far from 1 . This stems from the fact that media has a psychological effect that can manipulate a potential tourist to visit or not visit a tourism destination. Zimbabwe tourism destination has suffered from negative media publicity and the attitude of potential tourists also became negative avoiding the country as an unsafe place to visit. Tourism marketing authorities in Zimbabwe should therefore manipulate media publicity avenues in order to win the minds and hearts of potential tourist thus branding it as a prime tourism destination.

Word of mouth reference: This is highly related to attitudinal loyalty (1.113) more than behavioural loyalty (2.301) as depicted in table 1 and figure 1 . The average means of the respondents shows that from a range between 1 and 5, the majority represented by 1.113 "strongly agree" that word of mouth reference triggers attitudinal brand loyalty more than behavioural brand loyalty. This is because for behavioural brand loyalty the average mean is 2.301, relatively far from 1 . This is because it takes a positive attitude for someone to refer others to visit a tourism destination. Conversely a negative attitude will lead to negative word of mouth about a certain tourism destination. Zimbabwe tourism brand has suffered immensely from negative word of mouth especially from those in the Western communities. A combination of image building and awareness creation activities will help in escalating a positive word of mouth and brand performance for the Zimbabwe tourism destination.

Speculation: Speculation is a behaviour thus aligning to the results of the research in table 1 and figure 1 above which denoted that the majority of respondents (1.553) alluded that it contributes to behavioural loyalty more than attitudinal loyalty (2.017). The statistical average mean of 1.1553 for behavioural loyalty is close to 1 in a range of 1 to 5 as compared to 2.017 for attitudinal loyalty. This means that the respondents relatively agreed that speculation promotes behavioural loyalty as compared to attitudinal loyalty. However, speculation is attributed and triggered by a wide range of activities. It can be aligned to perception which is controlled by the image, awareness and word of mouth. This therefore 
means that image building is at the forefront in enhancing brand loyalty of a tourism destination.

\section{Recommendations}

Zimbabwe tourism destination authorities should invest in mechanisms that help in improving positive publicity of the country. This can be in the form of media and alliances with various local, regional and international partners who can help in spreading positive news about Zimbabwe to the world. This effort will help in countering negative vitriol that has tarnished the tourism destination and changing the state of tourists towards a positive attitudinal and behavioural loyalty on the country's tourism brand.

Familarisation tours should be engaged in order to encourage reality and moment of truth evidence rather than mere speculations by tourist. This will help in realigning both attitudinal and behavioural loyalty of the tourists. When tourists know the real truth about Zimbabwe as a tourism destination, they might change their perception and become loyal to the brand.

Partnering with other regional and international countries that have been reckoned as successful tourism destinations in advertising and promoting tourism offerings will help change the attitudinal and behavioral loyalty of tourists. This can be through co-hosting expos, indabas and other showcasing events that improve publicity.

\section{Conclusion}

Attitudinal loyalty has been discovered as a major driver for improving Zimbabwe's tourism brand performance. This is because individuals and organisations have been on the forefront in spreading negative publicity over the country's socio-economic and political downfall. They have spread news through various media to other potential tourists discouraging them to visit Zimbabwe regarding it as unsafe for humans. Their voice has been successful in destroying the Zimbabwe tourism destination brand. Behavioural loyalty has only discouraged few individuals who have had their direct personal issues with the country especially those from western countries who were against the government's land reform program. To a greater extent attitudinal loyalty has played a part in discouraging others to patronize the Zimbabwe tourism brand whilst behavioural loyalty has discouraged repeat consumption of the Zimbabwe tourism brand.

\section{References}

Bandyopadhyay, S., \& Martell, M. (2007). Does attitudinal loyalty influence behavioral loyalty? A theoretical and empirical study. Journal of Retailing and Consumer Services, 14, 35-44. http://dx.doi.org/10.1016/j.jretconser.2006.03.002

Bove, L. L., Pervan, S. J., Beatty, S. E., \& Shiu, E. (2009). Service worker role in encouraging customer organizational citizenship behaviors. Journal of Business Research, 62(7), 698-705. http://dx.doi.org/10.1016/j.jbusres.2008.07.003 
Carpenter, J. M. (2008). Consumer shopping value, satisfaction and loyalty in discount retailing. Journal of Retailing and Consumer Services, 15(5), 358-363. http://dx.doi.org/10.1016/j.jretconser.2007.08.003

Chaudhuri, A., \& Holbrook, M. B. (2001). The Chain of Effects from Brand Trust and Brand Affect to Brand Performance: The Role of Brand Loyalty. Journal of Marketing, 65(April), 81-93. http://dx.doi.org/10.1509/jmkg.65.2.81.18255

Chibaya, T. (2013). From 'Zimbabwe Africa’s Paradise to Zimbabwe A World of Wonders': Benefits and Challenges of Rebranding Zimbabwe as A Tourist Destination. Developing Country Studies, 13(5), 84-91.

Chikafu, J., Mirimi, K., \& Hurombo, B. (2014). Destination Rebranding Paradigm in Zimbabwe: A Stakeholder Approach. International Journal of Advanced Research in Management and Social Sciences, 3(1), 30-41.

Day, G. S. (1969). A Two-Dimensional Concept of Brand Loyalty. Journal of Advertising Research, 9(3), 29-35

Fullerton, G. (2005). The Impact of Brand Commitment on Loyalty to Retail Service Brands. Canadian Journal of Administrative Sciences, 22(2), 97-110. http://dx.doi.org/10.1111/j.1936-4490.2005.tb00712.x

Jones, T. O., \& Sasser, W. E. (1995). Why satisfied customers defect. Harvard Business Review, 73(6), 88-99.

Kumar, V., Shah, D., \& Venkatesan, R. (2006). Managing Retailer Profitability-One Customer at a Time. Journal of Retailing, 82(4), 277-294. http://dx.doi.org/10.1016/j.jretai.2006.08.002

Labeaga, J. M., Lado, N., \& Martos, M. (2007). Behavioral Loyalty towards Store Brands. Journal of Retailing and Consumer Services, 14, 347-356. http://dx.doi.org/10.1016/j.jretconser.2007.01.001

Lam, S. Y., Shankar, V., Erramilli, M. K., \& Murthy, B. (2004). Customer value, satisfaction, loyalty, and switching costs: an illustration from a business-to-business service context. Journal of the Academy of Marketing Science, 32(3), 293-311. http://dx.doi.org/10.1177/0092070304263330

Reynolds, K. E., \& Arnold, M. (2000). Customer Loyalty to the Salesperson and the Store: Examining Relationship Customers in an Upscale Retail Context. Journal of Personal Selling \& Sales Management, 20(2), 89-98.

Sharp, A., Sharp, B., \& Wright, M. (2002). Questioning the value of the True brand loyalty distinction. International Journal of Research in Marketing, 19(1), 81-90. 


\section{Copyright Disclaimer}

2015, Vol. 3, No. 2

Copyright for this article is retained by the author(s), with first publication rights granted to the journal.

This is an open-access article distributed under the terms and conditions of the Creative Commons Attribution license (http://creativecommons.org/licenses/by/3.0/). 